\title{
Effects of flooding regime on the feeding activity and body condition of piscivorous fish in the Upper Paraná River floodplain
}

\author{
Luz-Agostinho, KDG. a, *, Agostinho, AA. ${ }^{\mathrm{a}}$, Gomes, LC. ${ }^{\mathrm{a}}$, Júlio-Jr., HF. ${ }^{\mathrm{a}}$ and Fugi, R. ${ }^{\mathrm{a}}$ \\ ${ }^{a}$ Núcleo de Pesquisas em Limnologia, Ictiologia e Aqüicultura, Universidade Estadual de Maringá - UEM, \\ Av. Colombo, 5790, CEP 87020-900, Maringá, PR, Brazil \\ bLimnobios, Av. Pioneiro Alicio Arantes Campolina, 1223A, \\ CEP 87020-750, Maringá, PR, Brazil \\ *e-mail: karla.dgla@gmail.com
}

Received November 7, 2008 - Accepted March 4, 2009 - Distributed June 30, 2009

(With 4 figures)

\begin{abstract}
Flood pulses affect floodplain enrichment via the incorporation of nutrients and terrestrial biomass. As a result, they positively affect the body condition of aquatic organisms. This paper evaluates whether the absence of floods (resulting from dam control) affects the feeding activity and body condition of piscivorous fish. In addition, whether piscivores respond similarly to alterations in the flooding regime was assessed. Five piscivorous species were selected (Acestrorhynchus lacustris, Hoplias aff. malabaricus, Plagioscion squamosissimus, Rhaphiodon vulpinus, and Salminus brasiliensis). The fish were captured in four distinct years and in three river subsystems with differentiated water level fluctuations (Ivinheira = not regulated; Baía = regulated by the Paraná River level; Paraná = regulated by dams). Feeding activity and body condition were evaluated using the mean values of the standard residuals generated by regression models between body and stomach weights and standard length and body weight (all log-transformed). Differences among years and subsystems were evaluated via two-way analysis of variance. Pearson and Spearman correlations were performed between flooding attributes (duration, amplitude, timing, and daily variability) and feeding activity and body condition. Feeding activity differed across subsystems, whereas body condition varied across years, depending on the subsystem. Hoplias aff malabaricus (an ambusher adapted to starvation) presented feeding activity independent of the flooding regime and also presented better body condition in times of high water levels. Rhaphidon vulpinus exhibited variations in feeding activity but did not present alterations in body condition. The other species presented poorer body condition in years or subsystems with regular floods. Correlations identified that the duration and timing of floods had negative effects on body condition, whereas amplitude and mean annual water level improved feeding activity. Therefore, regular floods affect the feeding activity and body condition of piscivorous fish, and the response of each species depends on the existence or absence of pre-adaptation to long periods of starvation. Consequently, considering the role of the flood pulse in determining the availability of feeding resources for early life stages of piscivores, control of the flood pulse by dams is also disadvantageous for piscivorous fish.
\end{abstract}

Keywords: floodplain, flood pulses, piscivorous, Paraná River.

\section{Efeitos do regime de cheias sobre a atividade alimentar e condição corporal de peixes piscívoros na planície de inundação do Alto Rio Paraná}

\section{Resumo}

Os pulsos naturais de cheias são considerados fundamentais para o sucesso no recrutamento de peixes e no enriquecimento das planícies de inundação pela incorporação de nutrientes e biomassa terrestre, atuando positivamente na condição dos organismos aquáticos. O presente trabalho pretende avaliar se a ausência dos pulsos anuais, resultantes do controle por reservatórios hidrelétricos, afeta a atividade alimentar e a condição corporal de peixes piscívoros e se este grupo trófico responde de maneira similar às alterações no regime de cheias. Para isto foram selecionadas cinco espécies: Acestrorhynchus lacustris, Hoplias aff. malabaricus, Plagioscion squamosissimus, Rhaphiodon vulpinus e Salminus brasiliensis, capturadas em quatro anos distintos e em três subsistemas com variações hidrométricas diferenciadas (Ivinheima, não regulado; Baía, influenciado pelo regime hídrico do Rio Paraná, e Rio Paraná, nível regulado por represas). A atividade alimentar e a condição corporal foram avaliados através dos valores médios dos resíduos padronizados, gerados pelas regressões entre os logaritmos do peso total e peso do estômago e peso total e comprimento padrão, respectivamente, sendo as diferenças entre anos e subsistemas avaliadas pela análise de variância fatorial (ANOVA). Correlações de Pearson e Spearman entre os atributos hidrográficos (duração, magnitude, 
época e variabilidade diária) e a atividade alimentar e condição corporal foram analisadas. A atividade alimentar foi diferente apenas entre os subsistemas, enquanto a condição variou entre os períodos conforme o subsistema. Hoplias aff. malabaricus, emboscadora e adaptada a anorexia, foi a única com atividade alimentar independente do regime de cheias e com melhor condição corporal em períodos de águas altas. $R$. vulpinus, embora com variações na atividade alimentar, não mostrou alterações na condição. Já, as demais espécies mostraram tendências de baixa condição corporal em períodos ou locais de cheias regulares. As correlações mostram que duração e início regular das cheias têm efeito negativo sobre a condição corporal dos indivíduos, enquanto a magnitude e os valores médios anuais foram benéficos à tomada de alimento. A variabilidade nos níveis diários da água correlacionou-se negativamente com a intensidade na tomada de alimento. Estes resultados demonstram que as cheias regulares afetam a atividade alimentar e a condição dos piscívoros e, a resposta dada depende da existência ou não de pré-adaptação a períodos prolongados de anorexia. Ressalta-se, entretanto, que dado o papel dos pulsos de cheias no recrutamento, na disponibilidade de recursos alimentares para as fases iniciais dos piscívoros, na atenuação do canibalismo e predação intra-guilda, o controle das cheias por represamentos é desastroso também para os piscívoros.

Palavras-chave: planície de inundação, pulso de cheias, peixes piscívoros, Rio Paraná.

\section{Introduction}

The integrity of processes that operate in floodplains is closely associated with the hydrological regime, and the alternation between flooding and drought periods determines the structure and functioning of these environments (Junk et al., 1989; Neiff, 1990; Junk and Wantzen, 2004; Thomaz et al., 2004; 2007; Raniere et al., 2008). It is expected that river water overflowing onto the floodplain will increase the availability of shelter and allochthonous food sources and enrich the water with nutrients carried down from slopes or nutrients present in flooded organic or inorganic materials (Agostinho et al., 2004a).

In the upper Paraná River floodplain, upstream reservoirs have caused a redistribution of historical seasonal water flows throughout the year, especially after the Porto Primavera reservoir - the nearest - was impounded. This event, which directly affected the flooding regimes of the Paraná and Baía Rivers and, to a lesser extent, the low portions of the Ivinheima River, is expected to have caused changes in the feeding and nutritional features of fish that live transiently or permanently in that region.

The influence of hydrological cycle attributes on migration, reproduction, juvenile survival, and recruiting activities have been widely discussed in the literature for this region (Agostinho et al., 1993; Gomes and Agostinho, 1997; Agostinho et al., 2004a, b; Gubiani et al., 2007). The literature also contains several studies examining the effect of the annual variation in water level on fish diet in the region (Almeida et al., 1997; Hahn et al., 2004; Russo, 2004; Luz-Agostinho et al., 2008) or the effect of regulation and nutrient retention on the food chain length (Hoeinghaus et al., 2008) and carbon flow patterns (Hoeinghaus et al., 2007). Studies on the effects of interannual variations in the flooding regime, especially on a scale involving periods prior to and following the construction of Porto Primavera Reservoir, on aspects related to food intake intensity and fish condition are nonexistent. In addition, it is expected that species that belong to different trophic categories present differ- entiated responses to water level variations. This possibility can even be extended to species with similar diets but different food intake strategies. Within this context, it is possible that piscivorous fish species are particularly affected and show distinct responses according to the strategy adopted.

The antagonistic effects of floods on piscivores are unexpected and possibly remarkable since flood duration and magnitude have a positive relationship with success in reproduction for many species that provide food for them (Bialetzki et al., 2005; Agostinho et al., 2004c; Suzuki et al., 2009; Fernandes et al., 2009) while reducing the density of previously existing species via the dilution effect and reducing prey availability by increasing the amount of available shelter in the form of flooded vegetation (Okada et al., 2003). The opposite effect is observed as the water line recedes, causing food to become more concentrated and available.

Due to the important role played by piscivores in the structuring and functioning of river-floodplain systems (Almeida et al., 1997), and in order to evaluate the effects of regulation imposed by dams on flooding attributes on this trophic group, we selected five piscivorous species based on their initial abundance and diversity of life strategies (Agostinho et al., 2007b): i) Acestrorhynchus lacustris (Lütken, 1875) - short distance migrant, no parental care and lentic water preference; ii) Hoplias aff. malabaricus (Bloch, 1794) - sedentary, with parental care and lentic water preference; iii) Rhaphiodon vulpinus Spix and Agassiz, 1829 - long distance migrant, no parental care and lotic water preference; iv) Plagioscion squamosissimus (Heckel, 1840) sedentary, no parental care, lentic water preference; and v) Salminus brasiliensis (Cuvier, 1816) - long distance migrant, no parental care and lotic water preference.

Therefore, considering a wide spatial scale, i.e., three subsystems of the high Paraná River floodplain submitted to different regulation influences caused by 
impoundment, as well as a wide temporal scale (four years with distinct water cycles), this work addressed two questions: i) does a lack of annual pulses affect the feeding activity and body condition of piscivores?; and ii) does the flood pulse control differently the feeding activity and body condition of piscivorous species with different feeding strategies?

\section{Materials and Methods}

Samplings were performed in the upper Paraná River floodplain at sampling points located in lake, channel, and river environments distributed among the Ivinheima, Baía, and Paraná Rivers, here referred to as subsystems (Figure 1).

The hydrological cycle data for the Ivinheima and Paraná Rivers were supplied by Itaipu Binacional's Hydrology Department and were obtained at the Porto Sumeca and Porto São José hydrological stations, respectively. The information obtained from the hydrographic database and considered as flooding regime attributes were flood duration (percentages of flooding days in relation to the hydrological cycle), season (2-week periods elapsed and month of first floods, based on historical data), magnitude (maximum and mean an- nual levels and mean level in the flooding period), and variability of levels (coefficient of variation calculated from daily data).

Individuals of five fish species were captured monthly in the period from March 1992 to Feb 1993 and quarterly in the years 2000, 2001 and 2002. Gill nets of different mesh sizes were used to capture the fish; the nets were exposed for a 24-hour period, with harvests at 8:00 AM, 4:00 PM and 10:00 PM. After harvesting, the A. lacustris, $H$. aff. malabaricus, P. squamosissimus, $R$. vulpinus, and $S$. brasiliensis individuals were measured, weighed and eviscerated for stomach weight and sex identification.

The mean feeding activity for the species per subsystem and year was evaluated via the mean standardized residual values generated by regressions between log-transformed total weight and stomach weight. The mean body condition by species was calculated from the mean standardized residual values generated by regressions between log-transformed total weight and standard length. To remove the effect of sex on body condition, we generated residuals for males and females separately (differences between sexes tested by ANCOVA). The coefficient of determination values obtained in these re-

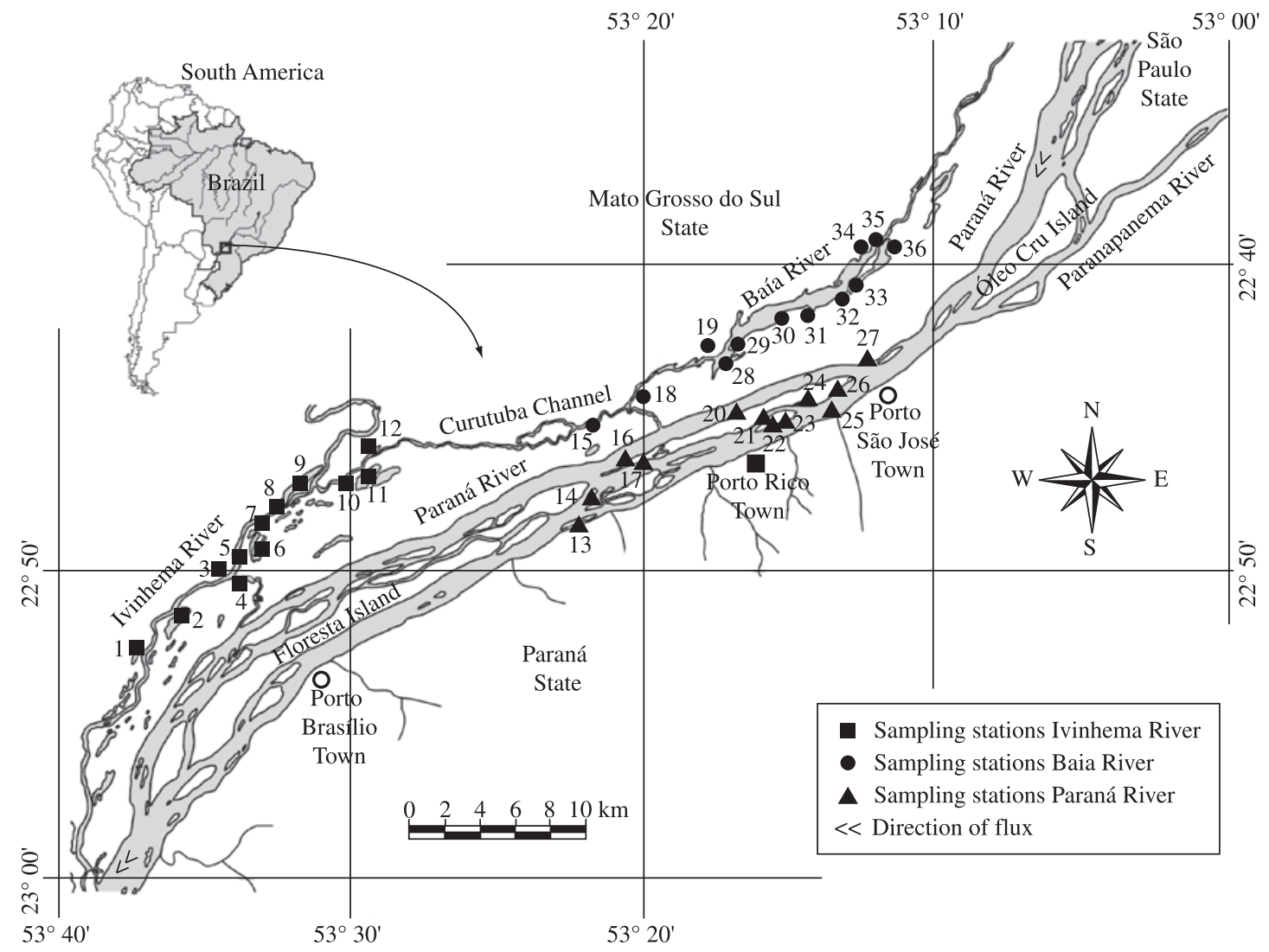

Figure 1. Locations of sampling stations in the high Paraná River floodplain: a Ivinheima Subsystem; • Baía Subsystem; and $\boldsymbol{\Delta}$ Paraná Subsystem. 
gressions were higher than 0.7 and 0.95 , respectively. In both cases, the significance levels of differences in standardized residual means for the subsystems and years and their interactions were tested by analysis of variance (two-way ANOVA). When differences were significant, discrimination between factor levels (subsystems and periods) was obtained by applying Tukey tests (Zar, 1996). The level of significance adopted for all analyses was $\mathrm{p}<0.05$.

The correlations between flood attributes and feeding activity and body condition were analyzed via Pearson's (linear) and Spearman's (nonlinear) correlation analyses using the Statistic v.7.0 software program.

\section{Results}

\subsection{Hydrological regime}

The daily level variations for the Ivinheima and Paraná Rivers in the periods from October 1991 to February 1993 and from October 1999 to September 2002 show that floods were more intense and lasted longer in the earlier period in both rivers (Figure 2).

In the Ivinheima River, less intense but relevant floods were observed in the subsequent periods. In the Paraná River, however, floods did not occur or were irrelevant in the three subsequent years, showing high weekly level fluctuations. Although rains were scarce in 2000 and 2001, the construction of the Porto Primavera reservoir about $40 \mathrm{~km}$ upstream contributed to this occurrence as well. The construction of the reservoir also contributed to the high-frequency water level pulses (daily and weekly) observed in that area during that period. The flow level data for the Baía River, the fish assemblage of which is also an object of analysis in this study, were not available for the entire period and were omitted. However, their variation is similar to that of the Paraná River, which runs nearby on a parallel course, and establishes surface contact with the Baía during major floods.

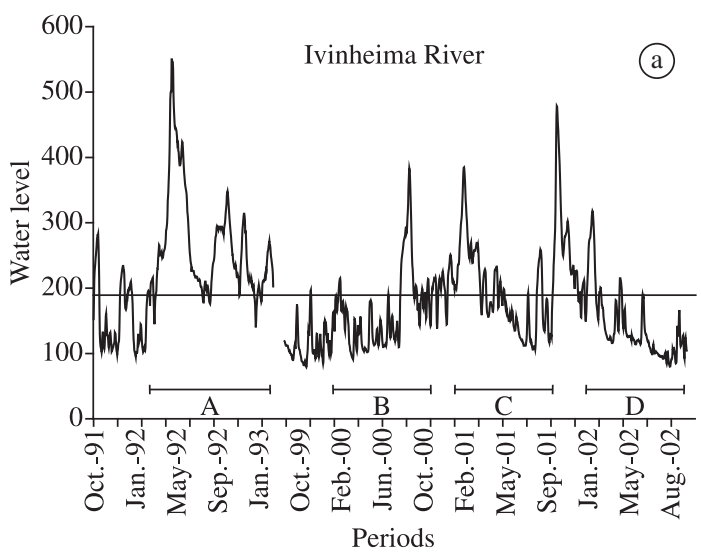

As demonstrated in Figure 2, the flooding regime attributes varied between the years and subsystems under consideration. The percentages of flooding days in relation to the hydrological cycle fluctuated between $1.4 \%$ (2001, Paraná) and 70.0\% (1992-93, Ivinheima), with the onset of floods occurring between October (1992-93 and 2001 in the Ivinheima River) and January (1992-93 in the Paraná rivers,) to March (2000, in both) - Table 1. The highest levels attained were $664 \mathrm{~cm}$ (Paraná River) and $558 \mathrm{~cm}$ (Ivinheima River), both in 1993-94. The estimated mean for the flooding period in the Paraná River was also the highest. This was not observed in the Ivinheima River in view of the shorter duration and smaller daily levels recorded during part of this period.

\subsection{Feeding activity variations}

The mean residuals for the relation between the logtransformed stomach weight (We) and total weight (Wt), which were used to make inferences about variations in the amount of food in the stomach (feeding activity), showed distinct patterns in individual species and in all species combined.

The analysis of variance applied to the residuals calculated for all species combined showed significant differences only between subsystems $(\mathrm{df}=2,5.411$; $\mathrm{F}=5.905 ; \mathrm{p}=0.002)$, indicating that feeding activity did not differ in a relevant manner between years $(\mathrm{df}=3$, 5.411; $\mathrm{F}=0.275 ; \mathrm{p}=0.842$ ). Thus, feeding activity was more intense in the Paraná (Tukey; $\mathrm{p}=0.0001$ ) and Baía subsystems (Tukey; $\mathrm{p}=0.0001$ ) than in the Ivinheima subsystem. Although feeding activity remained higher than in the Ivinheima subsystem in subsequent years (Tukey; $\mathrm{p}=0.015 ; \mathrm{p}=0.049$ ) (Figure 3 ), this pattern was more evident in the first year (1992-93).

This analysis, performed for each species, reveals the absence of an influence of year on the feeding activity of piscivores. Significant feeding activity differences among subsystems were found for $P$. squamosissimus (df $=2,341 ; \mathrm{F}=4.750 ; \mathrm{p}=0.0092)$ and $R$. vulpinus $(\mathrm{df}=2,947 ; \mathrm{F}=4.625 ; \mathrm{p}=0.010)$ and for the interaction

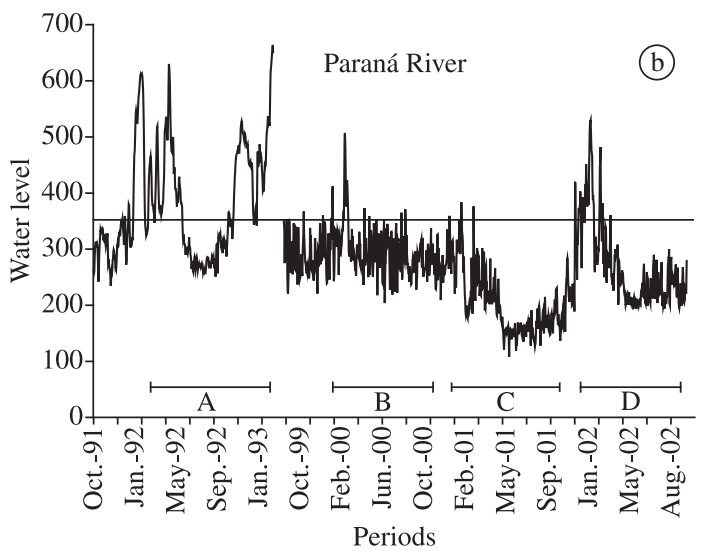

Figure 2. Daily river level variations (streamflow heights) during the hydrological cycles in which samplings were performed (solid line represents the mean values for the period). 
Table 1. Hydrological regime attribute values in the two main subsystems sampled in each period $(\mathrm{CV}=$ coefficient of variation).

\begin{tabular}{clcccc}
\hline \multirow{2}{*}{ Subsystems } & \multicolumn{1}{c}{ Attributes } & \multicolumn{3}{c}{ Years } \\
\cline { 2 - 5 } Ivinheima River & Duration (\%) & $\mathbf{( 1 9 9 2 - 9 3 )}$ & $\mathbf{( 2 0 0 0 )}$ & $\mathbf{( 2 0 0 1 )}$ & $(\mathbf{2 0 0 2})$ \\
& Start & 10.0 & 10.7 & 51.2 & 30.8 \\
& Maximum (cm) & 558 & $1 /$ Mar. & $1 /$ Oct. & $2 /$ Nov. \\
& Mean (year, cm) & 231.5 & 191 & 193 & 287 \\
& CV (\%) - year & 38.8 & 39.3 & 195.6 & 170.7 \\
& Mean (flooding, cm) & 196.8 & 126.7 & 27.8 & 45.1 \\
& CV (\%) - flooding & 32.2 & 27.1 & 221.0 & 202.1 \\
Paraná River & Duration (\%) & 49.4 & 7.9 & 1.4 & 42.9 \\
& Start & $1 /$ Jan. & $2 /$ Mar. & $2 /$ Feb. & $2 /$ Feb. \\
& Maximum (cm) & 664 & 507 & 384 & 530 \\
& Mean (year, cm) & 380.69 & 298.45 & 228.74 & 251.38 \\
& CV (\%) - year & 26.4 & 14.1 & 26.5 & 29.6 \\
& Mean (flooding, cm) & 397.7 & 304.4 & 271.9 & 259.8 \\
& CV (\%) - flooding & 25.09 & 15.79 & 14.79 & 35.35 \\
\hline
\end{tabular}

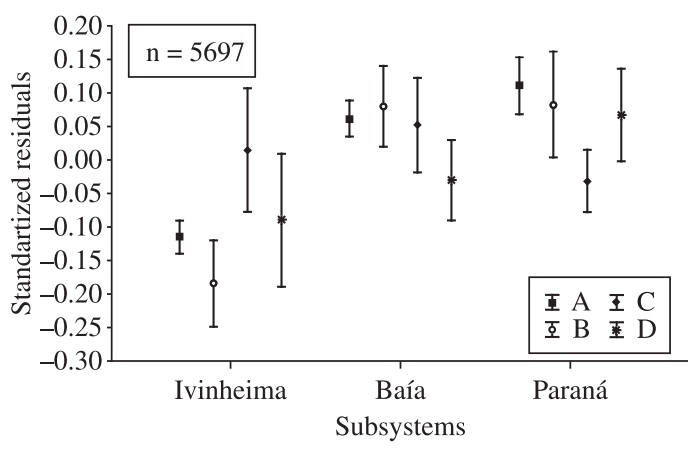

Figure 3. Mean standardized residual values for the relation between stomach weight and total weight logarithms ( \pm standard error) of the piscivores under consideration in different subsystems and sampling periods; $\mathrm{n}=$ number of individuals analyzed. (A = Mar., 1992 to Feb., 1993; $B=2000 ; C=2001 ; D=2002)$.

between subsystems and years in A. lacustris ( $\mathrm{df}=6$, $1995 ; \mathrm{F}=2.151 ; \mathrm{p}=0.045)$. No differences were observed between years and subsystems for the feeding activity of $H$. aff. malabaricus ( $\mathrm{p}>0.05$ ), while failure to capture $S$. brasiliensis in at least one of the years made this evaluation impossible.

\subsection{Variations in body condition}

The body condition of the piscivorous fish under consideration varied between subsystems $(\mathrm{df}=2$, 5.389; $\mathrm{F}=32.277 ; \mathrm{p}<0.0001)$ and years $(\mathrm{df}=3,5.389$; $\mathrm{F}=41.612 ; \mathrm{p}<0.0001)$. However, interactions were observed between these two factors $(\mathrm{df}=6,5.389$; $\mathrm{F}=15.966 ; \mathrm{p}<0.0001)$. While making it harder to evaluate the significance of differences between means observed in different subsystems and years individu- ally, this interaction corroborates the negative relation of floods with piscivore condition since different subsystems showed distinct annual flooding regimes during the considered time interval. However, in general, the piscivores analyzed in the Ivinheima River were in poorer body condition than those in the other subsystems, except for 1992-93, when the estimated condition means for the subsystems were similar. The greatest condition means were observed in 2000 in the Baía subsystem; in the other years, both in this and in the Paraná River subsystem, means assumed intermediate values (Figure 4).

This analysis by species shows three basic variation patterns in which $R$. vulpinus did not show spatial (df $=2$, 930; $\mathrm{F}=0.990 ; \mathrm{p}=0.372$ ) or temporal variations $(\mathrm{df}=3,930 ; \mathrm{F}=0.341 ; \mathrm{p}=0.796)$ in body condition; A. lacustris and P. squamosissimus showed poorer body conditions in the first year (1992-93) in all subsystems; and $H$. aff. malabaricus showed opposite variation trends. As expected, the interactions between subsystem and year were significant for these species ( $\mathrm{F}>2.47$; $\mathrm{p}<0.05)$. The condition of $S$. brasiliensis was better in the Paraná River in 1992-93. For the other years, the low number of individuals collected did not permit any interpretation (Figure 4).

\subsection{Correlations between floods and feeding activity/ body condition}

Correlations between flooding attributes and feeding activity showed that the latter is positively related (Pearson's $r$ and Spearman's $\rho$ ) to maximum annual river levels (Max-year), mean annual levels (Mean-year), and mean levels during floods (Mean-Flood). The latter attribute has the highest correlation value. Variability in daily levels, especially on an annual scale (CV-year), was negatively correlated with food intake intensity (Table 2). 

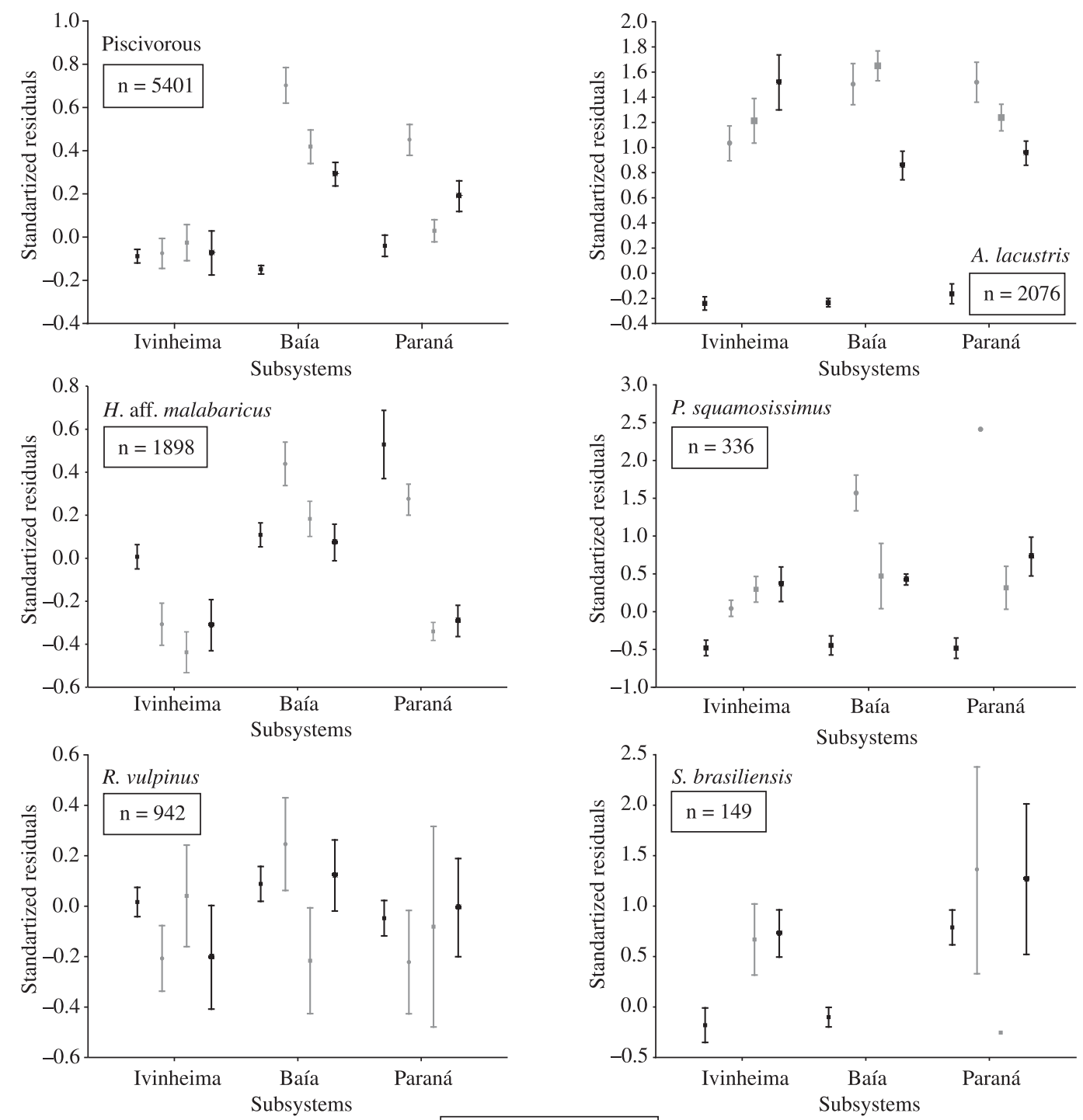

平 $\mathrm{A}$ 更 $\mathrm{C}$ 互 I $\mathrm{D}$

Figure 4. Mean standardized residual values for the relation between total weight and standard length logarithms ( \pm standard error) of the piscivores under consideration in different subsystems and sampling periods; $\mathrm{n}=$ number of individuals analyzed. (A = Mar., 1992 to Feb., 1993; B = 2000; C = 2001; D = 2002).

Table 2. Pearson and Spearman correlation values between flooding attributes, relative stomach weights (feeding activity), and relative weight of individuals (body condition) in the Paraná River floodplain (for the meaning of attributes, see text); $*$ = significant correlations.

\begin{tabular}{|c|c|c|c|c|}
\hline \multirow[t]{2}{*}{ Attributes } & \multicolumn{2}{|c|}{$\begin{array}{c}\text { Feeding activity } \\
\text { (Mean residual for the We } \times \mathrm{Wt}^{*} \text { relation) }\end{array}$} & \multicolumn{2}{|c|}{$\begin{array}{l}\text { Body condition } \\
\text { (Mean residual for the } \mathrm{Wt} \times \mathrm{Lt}^{*} \text { relation) }\end{array}$} \\
\hline & Pearson & Spearman & Pearson & Spearman \\
\hline Duration & -0.07 & -0.07 & $-0.65 *$ & $-0.70 *$ \\
\hline Start & 0.21 & 0.20 & $0.65^{*}$ & $0.71 *$ \\
\hline Max - year & $0.78^{*}$ & $0.80 *$ & 0.22 & 0.16 \\
\hline Mean - year & $0.82 *$ & $0.83 *$ & 0.14 & 0.17 \\
\hline CV - year & $-0.79 *$ & $-0.80 *$ & $-0.71 *$ & -0.50 \\
\hline Mean - flood & $0.89 *$ & $0.93 *$ & 0.16 & 0.30 \\
\hline CV - flood & -0.32 & -0.33 & -0.48 & -0.48 \\
\hline
\end{tabular}


The condition of individuals, considering the piscivores analyzed globally, was positively correlated with the beginning of floods as established according to the number of 2-week periods elapsed and compared against values obtained from the historical hydrologic cycles for the region. In this case, late floods produce more robust piscivores. Negative correlations with the body condition of individuals were verified for flood duration (Duration) and variability in annual river levels ( $\mathrm{CV}$-year). These results demonstrate that, although some flooding attributes have positive impacts on food intake, floods negatively affect piscivores' condition.

\section{Discussion}

Even though the effects of natural flooding regime regulation in floodplains have been addressed in several publications worldwide (Welcomme, 1979; LoweMcConnell, 1999; Bayley, 1995; Agostinho et al., 2004c, Raniere et al., 2008), responses of a trophic nature have received less attention than those related to reproduction, recruiting, and community alterations. The rare studies available have a mono-specific character (Gomes and Agostinho, 1997) or include species of a single genus (Jepsen et al., 1997; 1999).

Among the piscivorous species analyzed, all ingest whole prey and show high empty stomach percentages $(>50 \%)$, a characteristic pattern of this trophic category. High empty stomach percentages indicate frequent shortduration negative energy balances and are related to the intake of large items with high energy content (Arrington et al., 2002). Thus, species that feed on organisms with these characteristics have less frequent daily food seeking and ingesting activity, and greater empty stomach percentages are expected.

The fact that river level variations were distinct in the subsystems and years considered were expected to lead to a strong interaction between these two factors in the analysis of their effects on piscivores' feeding activity. However, differences were observed in relation to subsystems only, which should reflect the complexity of the piscivores' responses to level variations. The antagonistic effects of floods on prey availability, diluting them and providing shelter on the one hand and favoring reproduction and the entry of seasonal fry species (sensu Winemiller, 1989) on the other, contribute to this complexity. In addition, the distinct responses produced by the various species under consideration, as will be discussed, contributed to these results.

The average condition of the piscivores varied across subsystems according to the year considered. Small and similar mean values were recorded during all hydrological cycles in the Ivinheima River and in the first year (1992-93) of the other subsystems. The facts that the flooding regime of the Ivinheima River basin was not affected by the control imposed by dams and that the highest river levels in the entire floodplain occurred in the first period (1992-93) indicate that the estimated pis- civore condition variations in this subsystem are natural. This tendency, together with reduced feeding activity in the Ivinheima River, indicates that floods have a negative impact on both variables; this was the only subsystem in which seasonal flooding continued to occur after the first year (1992-93).

The reduction in river levels leads, at least for some time, to an increase in fish density, benefiting piscivores (Jepsen et al., 1999; Winemiller, 2003). During the water receding period, biotic interactions, especially those of a predator-prey type, are more intense (Winemiller, 2003). This stage of the hydrological cycle presents suitable body conditions to allow large migratory piscivores to restore their reserves, which become depleted in the migratory and reproductive processes (Agostinho et al., 2007a; Abujanra et al., 2009). Similar tendencies were reported by Gimenes and Dos Anjos (2006) for wading birds in the upper Paraná River floodplain.

When droughts occur continuously for several years, however, the abundance and availability of prey are generally affected, with consequences on the feeding activity and body condition of this trophic category. The observed decreases in the average feeding activity and body condition of piscivores in the Paraná and Baía Rivers after the first dry year, followed by an interruption of this tendency in the Paraná River when the magnitude and duration of floods showed a slight increase, are in accord with this theory. Jepsen et al. (1999) evaluated the growth and condition of "tucunaré" species in rivers and reservoirs in Venezuela and reported that these predators intensify their feeding activities during the low water period, increasing their growth rates and body condition averages. However, the depletion of their prey populations influences the abundance of resources, especially during prolonged drought periods.

The hydrological regime, however, has different attributes that should be considered, among which are the duration, magnitude, season, and variability of pulses. The correlations established between piscivore mean feeding activity and body condition values and different hydrographic attributes show distinct patterns of responses to these attributes. Flooding duration, which plays a relevant role in recruiting (Agostinho et al., 2004b), has been negatively correlated with piscivore condition, suggesting that the prey dilution and shelter availability effects exceeded the benefits derived from their abundance. This variable did not influence feeding activity, which suggests that although flooding duration does not reduce food intake, a great deal of energy must be spent seeking it. On the other hand, daily level fluctuations, which cause instability, particularly in littoral areas (SouzaFilho et al., 2004), negatively affected body condition and food intake. The positive correlations found between the beginning of floods and body condition also demonstrate that the regular flooding cycle, shown by historical series to begin in October (Agostinho et al., 2007a,b), is adverse to piscivores' condition as well, since piscivores present better body condition in cycles with late 
floods. The fact that flooding duration is not related to the beginning of the floods indicates the independence of this factor's influence. An investigation by Agostinho et al. (2004b) revealed that the reproduction of sedentary species and of most species that exhibit parental care (opportunistic and equilibrium, sensu Winemiller, 1989) is more intense in dry years and that mortality caused by predation markedly reduces the abundance of these species. A delayed beginning of floods may therefore favor the availability of these prey since, in general, these species reproduce before the floods (Winemiller, 2003). Concerning the positive effects of water level means and the magnitude reached by flooding peaks on feeding activity, it is interesting to note that these were not reflected in body condition, also suggesting a high energy cost to maintain this activity.

The piscivorous species analyzed responded differently to the subsystem and year conditions. An explanation for this tendency could be sought in the distinct strategies they exhibit. Thus, $H$. aff. malabaricus, which did not change its feeding activity in the various years and subsystems, experienced its best body condition in the year with lasting floods and a tendency of reduction in the last two years, although this marker did show a strong dependence on the subsystem under consideration. These patterns were distinct from those of other species, from which $H$. aff. malabaricus differs in having a different prey capture strategy (ambusher, Paiva et al., 1994) wherein it uses structured environments in which juveniles and small-sized species seek refuge during floods (Delariva et al., 1994; Súarez et al., 2001). Other characteristics, such as solitary habits, sedentarism, and nocturnal activity (Oliveros and Rossi, 1991; Hahn et al., 2004), also separate this species from the majority of the other species. In addition, and uniquely among species that provide parental care (Prado et al., 2006), it presents trophic adaptations to long starvation periods (Paiva et al., 1994; Rios et al., 2002). This fact was demonstrated by the greater incidence of empty stomachs ( $>70 \%$ in any one year or subsystem) and has drawn the attention of many authors (Caramaschi, 1979; Oliveiros and Rossi, 1991; Almeida, 1999; Loureiro and Hahn, 1996; Hahn et al., 2004). Arrington et al. (2002) reported that piscivorous species that present nocturnal habits and parental care generally use the energy stored during periods of favorable conditions as a metabolic substrate during periods of negative energy balance (without feeding). According to Rios et al. (2002), this species can survive up to 180 days of food deprivation without reductions in metabolism. Hepatic reserves are mobilized for 30 days of starvation, but perivisceral fat bodies take 240 days to be completely depleted. These authors report that when H. malabaricus is hypometabolic, normal metabolic rates are rapidly restored upon refeeding.

The feeding activity and body condition of the other species varied depending on subsystem and/or year, except for $R$. vulpinus, which demonstrated no effect of year. The other species are generally open water dwellers, pursuers, with diurnal (A. lacustris and S. brasiliensis) or indifferent habits ( $P$. squamosissimus) - (Sazima, 1986; Almeida, 1999; Hahn et al., 1999), having greater or smaller relations with the margins (Bennemann and Shibatta, 2002). These species in general showed poorer body conditions in the year with the greatest floods, regardless of feeding activity.

Rainy or flooding periods have been considered favorable for feeding and nutritional reserve accumulation in fish, due to the entry of biomass carried by runoff (Bennemann et al., 1996), access to resources in the areas newly incorporated into the aquatic environment (Junk, 1985; Machado-Allison, 1992; Lowe McConnell, 1999), or success in flood-dependent aquatic fauna reproduction (Loureiro and Hahn, 1996). This relation could be true for some trophic groups, particularly detritivores (Gomes and Agostinho, 1997; Almeida et al., 1993), herbivores (Bennemann et al., 1996; Goulding et al., 1988; Loubens and Panfili, 2001), and omnivores (Bayley, 1988). For piscivores, however, our results have shown opposite trends, although with variations depending on the strategy adopted by the species. Abujanra et al. (2009) observed similar trends for others trophic groups.

It should be highlighted, nevertheless, that the decline in body condition resulting from prolonged, in addition to temporary and natural, flooding periods is widely compensated for in these species by greater recruiting, particularly in species with migratory strategies, or even by an expected reduction in cannibalism and intraguild predation. As noted by Jepsen et al. (1999), piscivores have been selected to store reserves during short periods (low water season) and use them in the following reproductive cycle. In addition, the flooding dynamic is essential in the plankton production process and in the life cycle of invertebrates (Junk et al., 1989; Aoyagui and Bonecker, 2004; Bonecker et al., 2005), which provide food for piscivorous species in their early stages. Therefore, because piscivores play an essential role in structuring assemblages as a reflex of top-down mechanisms, the impacts of floods' absence on this group constitute an additional risk factor for conservation of this important basin segment.

Acknowledgements - This study was financed by the "Long-Term Ecological Research" (PELD) program of CNPq. Angelo Antonio Agostinho and Luiz Carlos Gomes have been continuously supported by CNPq productivity fellowships. Karla D. G. Luz Agostinho was supported by CNPq graduate fellowships. Authors are grateful to the field team of Nupelia and PEA (Universidade Estadual de Maringá) by the logistic support during sampling and to Jaime Luiz Lopes Pereira for the illustrations.

\section{References}

ABUJANRA, F., AGOSTINHO, AA. and HAHN, NS., 2009. Effects of the flood regime on the body condition of fish of different trophic guilds, in the Upper Paraná River floodplain, Brazil. Revista Brasileira de Biologia = Brazilian Journal of Biology. vol. 69, no. (2 suppl), p. 469-479. 
AGOSTINHO, AA., GOMES, LC. and PELICICE, FM., 2007a. Ecologia e manejo dos recursos pesqueiros em reservatórios do Brasil. Maringá: EDUEM. 501p.

AGOSTINHO, AA., GOMES, LC., THOMAZ, SM. and HAHN, NS., 2004a. The Upper Paraná River and its floodplain: main characteristics and perspectives for management and conservation. In THOMAZ, SM., AGOSTINHO, AA. and HAHN, NS. (Eds.). The upper Paraná River and its floodplain: physical aspects, ecology and conservation. Leiden: Backhuys Publishers. p. 381-393.

AGOSTINHO, AA., GOMES, LC., VERÍSSIMO, S. and OKADA, EK., 2004c. Flood regime, dam regulation and fish in the Upper Paraná River: effects on assemblage attributes, reproduction and recruitment. Reviews in Fish Biology and Fisheries, vol. 14, no. 1, p. 11-19.

AGOSTINHO, AA., PELICICE, FM., PETRY, AC., GOMES, LC. and JÚLIO Jr., HF., 2007b. Fish diversity in the upper Paraná River basin: habitats, fisheries, management and conservation. Journal of Aquatic Ecosystem Health and Management, vol. 10, no. 2, p. 174-186.

AGOSTINHO, AA., THOMAZ, SM. and GOMES, LC., 2004b. Threats for biodiversity in the floodplain of the upper Paraná River: effects of hydrological regulation by dams. Ecohydrology \& Hydrobiology, vol. 4, no. 3, p. 255-268.

AGOSTINHO, AA., VAZZOLER, AEAM., GOMES, LC. and OKADA, EK., 1993. Estratificación espacial y comportamiento de Prochilodus scrofa en distintas fase del ciclo de vida, en la planície de inundación del alto rio Paraná y embalse de Itaipu, Paraná, Brasil. Revue d'Hydrobiologie Tropicale, vol. 26, no. 1, p. 79-90.

ALMEIDA, VLL., 1999. Atividade alimentar diária de cinco espécies de peixes piscívoros da planície de inundação do alto rio Paraná, Brasil. Maringá: Universidade Estadual de Maringá - UEM. 52p. Tese de Doutorado.

ALMEIDA, VLL., HAHN, NS. and VAZZOLER, AEAM., 1997. Feeding patterns in five predatory fishes of the high Paraná River floodplain (PR, Brazil). Ecology of Freshwater Fish, vol. 6, no. 3, p. 123-133.

ALMEIDA, VLL., RESENDE, EK., LIMA, MS. and FERREIRA, CJA., 1993. Dieta e atividade alimentar de Prochilodus lineatus no pantanal do Miranda-Aquidauana, Mato Grosso do Sul, Brasil. Revista Unimar, vol. 15, no. 3, p. $125-141$

AOYAGUI, ASM. and BONECKER, CC., 2004. Rotifers in different environments of the Upper Paraná River floodplain (Brazil): richness, abundance and the relationship with connectivity. Hydrobiologia, vol. 522, no. 1-3, p. 281-290.

ARRINGTON, DA., WINEMILLER, KO., LOFTUS, WF. and AKIN, S., 2002. How often do fishes "run on empty"? Ecology, vol. 83 , no. 8 , p. 2145-2151.

BAYLEY, PB., 1988. Factors affecting growth rates of young tropical floodplain fishes: seasonality and density-dependence. Environmental Biology of Fishes, vol. 21, no. 2, p. 127-142.

, 1995. Understanding large river-floodplain ecosystems. BioScience, vol. 45, no. 3, p. 153-158.

BENNEMANN, ST. and SHIBATTA, OA., 2002. Dinâmica de uma assembléia de peixes do rio Tibagi. In Medri, ME., Biachini, E., Shibatta, OA. and Pimenta, JA. (Eds.). A bacia do Rio Tibagi. Londrina: Universidade Estadual de Londrina UEL. p. 433-442.
BENNEMANN, ST., ORSI, ML. and SHIBATTA, OA., 1996. Atividade alimentar de espécies de peixes do rio Tibagi, relacionada com o desenvolvimento de gordura e das gônadas. Revista Brasileira de Zoologia, vol. 13, no. 2, p. 501-512.

BIALETZKI, A., NAKATANI, K., SANCHES, PV., BAUMGARTNER, G. and GOMES, LC., 2005. Larval fish assemblage in the Baía River (Mato Grosso do Sul State, Brazil): temporal and spatial patterns. Environmental Biology of Fishes, vol. 73, no. 1, p. 37-47.

BONECKER, CC., COSTA, CL., VELHO, LFM. and TÔHA, FAL., 2005. Diversity and abundance of the planktonic rotifers in different environments of the Upper Paraná River floodplain (Paraná State - Mato Grosso do Sul State, Brazil). Hydrobiologia, vol. 546, no. 1, p. 405-414.

CARAMASCHI, EMP., 1979. Reprodução e alimentação de Hoplias malabaricus (Bloch, 1794) na represa do rio Pardo (Botucatu, SP) (Osteichthyes, Cypriniformes, Erythrinidae). São Carlos: Universidade Federal de São Carlos - UFSCar. 144p. Dissertação de Mestrado.

DELARIVA, RL., AGOSTINHO, AA., NAKATANI, K. and BAUMGARTNER, G., 1994. Ichthyofauna associated to aquatic macrophytes in the upper Paraná River floodplain. Revista Unimar, vol. 6, no. 3, p. 41-60.

FERNANDES, R., AGOSTINHO, AA., FERREIRA, EA., PAVANELLI, CS., SUZUKI, HI., LIMA, DP. and GOMES, LC., 2009. Effects of the hydrological regime on the ichthyofauna of riverine environments of the Upper Paraná River floodplain. Revista Brasileira de Biologia = Brazilian Journal of Biology, vol. 69 , no. (2 suppl), p. 669-680.

GIMENES, MR. and Dos ANJOS, L., 2006. Influence of lagoons size and prey availability on the wading birds (Ciconiiformes) in the upper Paraná River floodplain, Brazil. Brazilian Archives of Biology and Technology, vol. 49, no. 3, p. 463-473.

GOMES, LC. and AGOSTINHO, AA., 1997. Influence of the flooding regime on the nutritional state and juvenile recruitment of the curimba, Prochilodus scrofa, Steindachner, in upper Paraná River, Brazil. Fisheries Management and Ecology, vol. 4, no. 4, p. 263-274.

GOULDING, M., CARVALHO, ML. and FERREIRA, EG., 1988. Rio Negro: rich life in poor water. The Hague: SBB Academic Publishing. 200p.

GUBIANI, ÉA., GOMES, LC., AGOSTINHO, AA. and OKADA, EK., 2007. Persistence of fish population in the upper Paraná River: effects of water regulation by dams. Ecology of Freshwater Fish, vol. 16, no. 2, p. 191-197.

HAHN, NS., FUGI, R. and ANDRIAN, IF., 2004. Trophic ecology of the fish assemblages. In THOMAZ, SM., AGOSTINHO, AA. and HAHN, NS. (Eds.). The upper Paraná River and its floodplain: physical aspects, ecology and conservation. Leiden: Backhuys Publishers. p. 247-269.

HAHN, NS., LOUREIRO, VE. and DELARIVA, RL., 1999. Atividade alimentar da curvina Plagioscion squamosissimus (Heckel, 1840) (Perciformes, Sciaenidae) no rio Paraná. Acta Scientiarum, vol. 21, no. 2, p. 309-314

HOEINGHAUS, DJ., WINEMILLER, KO. and AGOSTINHO, AA., 2007. Landscape-scale hydrologic characteristics differentiate patterns of carbon flow in large-river food webs. Ecosystems, vol. 10, no. 6, p. 1019-1033.

2008. Hydrogeomorphology and river impoundment affect food-chain length of diverse Neotropical food webs. Oikos, vol. 117, no. 7, p. 984-995. 
JEPSEN, DB., WINEMILLER, KO. and TAPHORN, DC., 1997. Temporal patterns of resource partitioning among Cichla species in a Venezuelan blackwater river. Journal of Fish Biology, vol. 51, no. 6, p. 1085-1108.

JEPSEN, DB., WINEMILLER, KO., TAPHORN, DC. and OLARTE, DR., 1999. Age structure and growth of peacock cichlids from rives and reservoirs of Venezuela. Journal of Fish Biology, vol. 55, no. 2, p. 433-450.

JUNK, WJ. and WANTZEN, KM., 2004. The flood pulse concept: new aspects, approaches and applications - an update. In WELCOMME, RL. and PETR, T. (Eds.). Proceedings of the Second International Symposium on the Management of large Rivers for Fisheries, February 11-14. Thailand: RAP Publication. p. 117-140

JUNK, WJ., 1985. Temporary fat storage, an adaptation of some fish species to the water level fluctuations and related environmental changes of the Amazon River. Amazoniana, vol. 9 , no. 3, p. 315-351.

JUNK, WJ., BAYLEY, PB. and SPARKS, RE., 1989. The flood pulse concept in river-floodplain systems. In DODGE, DP. (Ed.). Proceedings of the International Large River Symposium (LARS). Ottawa: Department of Fisheries and Oceans. p. 110-127. Canadian Special Publication of Fisheries and Aquatic Sciences, 106.

LOUBENS, G. and PANFILI, J., 2001. Biologie de Piaractus brachypomus Teleostei: serrasalmidae dans basin du Mamoré Amazonie bolivienne. Ichthyological Exploration of Freshwaters, vol. 12, no. 1, p. 51-64

LOUREIRO, VE. and HAHN, NS., 1996. Dieta e atividade alimentar da traíra, Hoplias malabaricus (Bloch, 1794) (Osteichthyes, Erythrinidae), nos primeiros anos de formação do reservatório de Segredo - PR. Acta Limnologica Brasiliensia, vol. 8 , no. 1, p. 195-205.

LOWE-McCONNELL, RH., 1999. Estudos ecológicos de comunidades de peixes tropicais. São Paulo: Editora da Universidade de São Paulo. 535p. Coleção Base.

LUZ-AGOSTINHO, KD., AGOSTINHO, AA., GOMES, LC. and JÚLIO Jr., HF., 2008. Influence of flood pulses on diet composition and trophic relationships among piscivorous fish in the upper Paraná River floodplain. Hydrobiologia, vol. 607, no. 1, p. 187-198.

MACHADO-ALLISON, A., 1992. Larval ecology of fish of Orinoco Basin. In HAMLETT, WC. (Ed.). Reproductive biology of South American vertebrates. New Cork: Springer. p. 45-59.

NEIFF, JJ., 1990. Ideas para la interpretación ecologica del Paraná. Interciencia, vol. 15, no. 6, p. 424-441.

OKADA, EK., AGOSTINHO, AA., PETRERE Jr., M. and PENCZAK, T., 2003. Factors affecting fish diversity and abundance in drying ponds and lagoons in the upper Paraná River basin, Brazil. Ecohydrology \& Hydrobiology, vol. 3, no. 1 , p. $97-110$

OLIVEIROS, OB. and ROSSI, LM., 1991. Ecologia trófica de Hoplias malabaricus (Pisces, Erythrinidae). Revista de la Asociación de Ciencias Naturales del Litoral, vol. 22, no. 2, p. $55-68$

PAIVA, MP., PETRERE Jr., M., PETENATE, AJ., NEPOMUCENO, FH. and VASCONCELOS, EA., 1994. Relationship between the number of predatory fish species and fish yield in large north-eastern Brazilian reservoirs. In COWX, IG. (Ed.). Rehabilitation of freshwater fisheries. Oxford: Osney Mead; Fishing News Books. p. 120-129.
PRADO, CP., GOMIERO, LM. and FROEHLICH, O., 2006. Spawning and parental care in Hoplias malabaricus (Teleostei, Characiformes, Erythrinidae) in the southern Pantanal, Brazil. Revista Brasileira de Biologia $=$ Brazilian Journal of Biology, vol. 66, no. 2B, p. 697-702.

RANIERE, G., SOUZA, C. and FREITAS, ECF., 2008. The influence of flood pulse on fish communities of floodplain canals in the Middle Solimões River, Brazil. Neotropical Ichthyology, vol. 6, no. 2, p. 249-255.

RIOS, FS., KALININ, AL. and RANTIN, FT., 2002. The effects of long-term food deprivation on respiration and haematology of the neotropical fish Hoplias malabaricus. Journal of Fish Biology, vol. 61, no. 1, p. 85-95.

RUSSO, MR., 2004. Ecologia trófica da ictiofauna de pequeno porte, em lagoas isoladas da planície de inundação do alto rio Paraná, Brasil. Maringá: Universidade Estadual de Maringá UEM. 38p. Tese de Doutorado.

SAZIMA, I., 1986. Similarities in feeding behavior between some marine and freshwater fishes in two tropical communities. Journal of Fish Biology, vol. 29, no. 1, p. 53-66.

SOUZA-FILHO, E., ROCHA, PC., COMUNELLO, E. and STEVAUX, JC., 2004. Effects of the Porto primavera dam on physical environment of the downstream floodplain. In THOMAZ, SM., AGOSTINHO, AA. and HAHN, NS. (Eds.). The upper Paraná River and its floodplain: physical aspects, ecology and conservation. Leiden: Backhuys Publishers. p. 55-74.

SÚAREZ, YR., PETRERE Jr., M. and CATELLA, AC., 2001. Factors determining the structure of fish communities in Pantanal lagoons (MS, Brazil). Fisheries Management and Ecology, vol. 8, no. 2, p. 173-186.

SUZUKI, HI., AGOSTINHO, AA., BAILLY, D., GIMENES, MF., JÚLIO Jr., HF. and GOMES, LC., 2009. Inter-annual variations in the abundance of young-of-the-year of migratory species in the upper Paraná River floodplain: relations with hydrographic attributes. Revista Brasileira de Biologia = Brazilian Journal of Biology, vol. 69, no. (2 suppl), p. 649-660.

THOMAZ, SM., BINI, LM. and BOZELLI, RL., 2007. Floods increase similarity among aquatic habitats in river-floodplains systems. Hydrobiologia, vol. 579, no. 1, p. 1-13.

THOMAZ, SM., PAGIORO, TA., BINI, LM., ROBERTO, MC. and ROCHA, RRA., 2004. Limnological characterization of the aquatic environments and the influence of hydrometric levels. In THOMAZ, SM., AGOSTINHO, AA. and HAHN, NS. (Eds.). The upper Paraná river and its floodplain: physical aspects, ecology and conservation. Leiden: Backhuys Publishers. p. 75-102.

WELCOMME, RL., 1979. Fisheries ecology of floodplain Rivers. London: Longman. $317 \mathrm{p}$.

WINEMILLER, KO., 1989. Patterns of variation in life history among South American fishes in seasonal environments. Oecologia, vol. 81, no. 2, p. 225-241.

2003. Floodplain river food webs: generalizations and implications for fisheries management. In Proceedings of the Second International Symposium on the Management og Large Rivers for Fisheries, Fevereiro 11-14. Phnom Penh; Kingdom of Cambodia: FAO Publications. p. 285-309.

ZAR, JH., 1996. Biostatistical analysis. Upper Saddle River: Prentice Hall. 620p. 